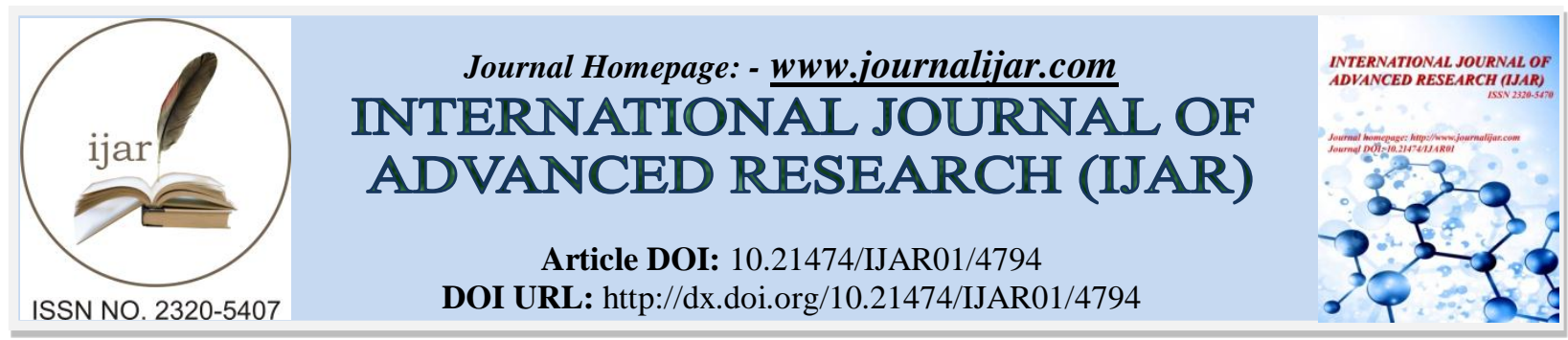

RESEARCH ARTICLE

\title{
DETERMINANTS OF QUALITY RESEARCH AND EXTENSION PROGRAMS OF THE COLLEGE OF TEACHER EDUCATION AT LAGUNA STATE POLYTECHNIC UNIVERSITY: AN ASSESSMENT.
}

Edilberto Z. Andal, Ed. D.

Dean, College of Industrial Technology, Laguna State Polytechnic University, San Pablo City Campus, Brgy. Del Remedio, San Pablo City, Laguna, Philippines 4000.

\section{Manuscript Info}

Manuscript History

Received: 9 May 2017

Final Accepted: 11 June 2017

Published: July 2017

Key words:-

Quality Research Programs; Quality

Extension Programs; Competence, Commitment and Work Values; Multiple

Regression Analysis

\begin{abstract}
This study assessed the quality and impact of research and extension (RDE) programs of the College of Teacher Education (CTE) at Laguna State Polytechnic University (LSPU) on the development of the clientele and communities. Specifically, it sought answers the profile of respondent; extent of compliance for quality research and extension programs; the differences on respondents' perceptions; and which variables taken singly or in combination significantly influence the quality of research and extension programs. Descriptive design was utilized with deans, directors, faculty, and staffs directly involved in RDE programs as respondents. Structured questionnaire adopted from AACCUP accreditation survey instruments with modifications was used. Mean, standard deviation, ANOVA, and multiple regression analysis were the statistical tools used. Majority of the respondents were 51 to 60 years of age, female; married; MA and Ed.D./Ph.D. holders. Their competence and commitment were rated very high; excellent work attitude, funding and resources components; while implementation, monitoring, evaluation, utilization of research results/outputs; publication and dissemination; priorities and relevance; planning; fund sourcing, community involvement and participation were rated high. Respondents perceived differently the quality of RDE programs and they concluded that respondents' profile and institutionrelated variables significantly influenced it; hence RDE quality and impact are felt by the stakeholders.
\end{abstract}

Copy Right, IJAR, 2017,. All rights reserved.

\section{Introduction:-}

Research and extension services as inherent functions of institution of higher learning, is tasked with initiating, catalyzing and sustaining the development of various communities by capitalizing on their expertise and viable resources.

However, not all higher education institutions all over the country have established research and extension centers to engage in research and to apply useful knowledge in the solutions of society's major problems. To accomplish the specific research and extension service functions of the college or university, they must come into closer contact with the community and the outside world that it serves. Both the faculty and the students should work cooperatively

Corresponding Author:- Edilberto Z. Andal, Ed.D.

Address:- Dean, College of Industrial Technology, Laguna State Polytechnic University, San Pablo City 880 Campus, Brgy. Del Remedio, San Pablo City, Laguna, Philippines 4000. 
to find their role in leadership and directions in realizing the mission, vision, goals, and objectives of the institution specifically in line with the needs and problems of the community.

Evidently, different research and extension programs, however, are the programs, thrusts and priorities of the college which should be planned and formulated based on the felt needs of the school, clientele, and community target beneficiaries.

Specifically, institutions of higher learning in the Philippines are now in the process of institutionalizing various program efforts that speak of quality and excellence through voluntary accreditation systems, programmatic research agenda pertaining with the community and business, for a more relevant and industry-oriented curriculum, and automation of various institutional processes for improved information delivery.

Educational institutions do not exist in a vacuum. The dynamism is inevitable. Advancements in science and technology, development in the work place, changes in student's demographics, and economic trends have led to the need to examine and redesign higher education and to meet the demands for globally competitive work skills, products, and services.

This concept of quality institutional performance increases the ability to explain standards of institutional effectiveness. It provides a means of explaining the institutional operations or institutional performance. Quality performance tells how much is accomplished towards an immediate goal and how effective a program has been in terms of the denominator of total need (Aramsi, 1999).

Performance measures could either be absolute, i.e., when assessed with respect to some previously defined or ideal features relative to a standard performance or to comparable aspect of another institution's performance. Thus, though organizations can achieve specific goals, much depend on the people working on them. Obviously, in school setting, the quality of performance is gauged through performance appraisal which is one of the best ways to measure effectiveness of organizational outcomes over which an organizational environment has control (De Chavez, 1999). Thus, it was the focus of this study to find out whether the College of Education at Laguna State Polytechnic University (LSPU) is performing to achieve its goals.

It is in this context that this research endeavor has been conceptualized. Research and Extension programs need to be conducted to identify the factors that influence the standards for institutional performance effectiveness.

It was the theoretical position of this study for the college to continue to be responsive to education and development needs of the country and to remain effective in its mandated thrust. As such, it called for strengthening their research, extension services, and production. The mandate for the renewal of teaching and learning and for the participation in the nation's growth and development through research and extension services provides the impetus from higher education institutions in the country to take the matter seriously. It made imperative the conduct of the study on this aspect- research and extension services.

\section{Research Framework:-}

In educational setting, quality should be seen in all aspects of instruction, research, extension services and production. CHED Commissioner Valisno (1997) emphasized that in meeting the qualitative demand for higher education depends not only on increasing its financial base, but also on a re-examination of its mission, objectives, curricular pattern and content, methods and techniques employed in the instructional process, the competence, interest and attitudes of the faculty, and those in charge of the management and governance of higher education.

The LSPU College of Teacher Education, in its desire to improve the quality of life of clientele, have identified themselves to be the center for providing quality education through initiating its effort in upgrading their curricular offerings and instruction in conjunction to research and extension programs.

These institutional functions of higher education institution, such as quality research and extension programs, were the dependent variables of this study using the instruments adopted from the AACCUP guidelines with some modifications. Each function was measured by the following indicators: the level of compliance on the quality of research program was measured in terms of priorities and relevance; funding and other resources; implementation, monitoring, evaluation and utilization of research results/outputs; and publication and dissemination. On the otherhand, the level of compliance on the quality of extension programs was measured in terms of priorities and 
relevance; planning, implementation, monitoring and evaluation; funding and other resources; and community involvement and participation in the institution's activities.

The independent variables in this study were the following: respondent-related factors, such as: age, gender, civil status, educational attainment, competence, commitment, and work attitude. b). institution-related factors, such as: programs and projects, accreditation level and funding sources.

The researcher came up with a model to illustrate the concept of this work (see Figure 1) which shows the relationship between independent, and dependent variables of the study.

\section{Research Paradigm:-}

Independent Variables

Related Factors

1. Respondent-Related factors

1.1 age

1.2 gender

1.3 civil status

1.4 educational attainments

1.5 competence

1.6 commitments

1.7 work attitude

2. INSTITUTION-RELATED FACTORS

2.1 programs and projects

2.5 accreditation level

2.6 funding sources
Dependent Variables

- Quality Research Program

- Priorities and Relevance

- Funding and other Resources

- Implementation, Monitoring, Evaluation and Utilization of Research Results/Outputs

- Publication and Dissemination

- Quality Extension Program

- Priorities and Relevance

- Planning

- Implementation, Monitoring and Evaluation

- Funding and Other Resources

- Community Involvement and Participation in the Institution's Activities

Figure 1:- Research Paradigm

Statement of the Problem:-

The main concern of this study was to find out the quality and impact of research and extension programs of CTE at LSPU on the development of the clientele and communities.

Specifically, this study sought answers to the following questions:

1. What is the profile of respondents as regards the following respondent-related factors?
1.1. age
1.2. gender
1.3. civil status
1.4. educational attainment
1.5. competence
1.6. commitment
1.7. work attitude

2. What is the status of research and extension programs of CTE at LSPU as regards:

2.1. programs and projects;

2.2. accreditation level; and

2.3. funding sources?

3. What is the extent of compliance of CTE at LSPU as assessed by Deans, Directors, Chairpersons, and Staff in the following components of quality research program?

3.1. priorities and relevance

3.2. funding and other sources 
3.3. implementation, monitoring, evaluation and utilization of research outputs

3.4. publication and dissemination

4. What is the extent of compliance of CTE at LSPU in the following aspects of quality extension program?

4.1. priorities and relevance

4.2. planning, implementation, monitoring, and evaluation

4.3. funding and other resources

4.4. community involvement and participation in the institution activities

5. Do the respondent-related factors and institution-related variables taken singly or in combination, significantly influence the quality of research and extension programs of the CTE at LSPU?

\section{Hypothesis:-}

The hypothesis tested in this study is:

The respondents-related factors and institution-related variables taken singly or in combination do not significantly influence the quality of research and extension programs of the CTE at LSPU.

\section{Methodology:- \\ Research Design:-}

Descriptive method was utilized primarily for the intention of the current research undertaking which is to describe current status of the research and extension programs of the CTE at LSPU. This was complemented by library researches and documentary analysis. The data were collected through a researcher-structured questionnaire based on AACCUP accreditation survey with some modifications. This questionnaire intended to describe the characteristics of the respondents. Furthermore, the study designed to draw out information related to the status of research and extension programs of the CTE at LSPU.

\section{Sampling Techniques:-}

The total population of 67 from the College of Teacher Education at LSPU was included in the study who are directly involved in research and extension programs of the college. They were 4 deans; 8 directors of research and extension services, 55 faculty and 4 RDE staffs from the said college of the University.

\section{Research Instruments:-}

The researcher-made questionnaire was the main research instrument used in gathering the data for the following groups of respondents; the deans, RDE directors, faculty and RDE staff. Personal and as well as institutional data such as; thrust of SUs, perceived vision and mission, goals and objectives, programs and projects, and extent of compliance of the CTE on the components of quality of research and extension programs were solicited. One set of questionnaire was utilized in gathering the necessary information on the personal characteristics and other identified variables pertaining to the quality of research and extension programs. It was personally administered by the researcher to the intended respondents such as deans, RDE directors, faculty and staff. The group of indicators measuring the extent of compliance of the College in the implementation of Research, Development and Extension Programs was interpreted using the following coding scale:

7 - (E) Excellent -The extent of compliance of College is from $85.8 \%$ to $100 \%$ level.

6 - (VH) Very High - The extent of compliance of College is from $77.5 \%$ to $85.7 \%$ level.

5 - (H) High - The extent of compliance of College is from $57.2 \%$ to $71.4 \%$ level.

4 - (A) Average - The extent of compliance of College is from $42.9 \%$ to $57.2 \%$ level.

3 - (L) Limited - The extent of compliance of College is from $28.6 \%$ to $42.8 \%$ level.

2 - (VL) Very Limited - The extent of compliance of College is from $14.3 \%$ to $28.5 \%$ level.

1 - (N) Negligible - The extent of compliance of College is from $1.0 \%$ to $14.2 \%$ level.

To establish validity, the instrument was pre-tested by experts who are familiar with research and extension work, such as the vice presidents, deans and other officials of private higher education institutions in the city. The instrument was pilot-tested among the private and LGU institutions not included in the study for purposes of the reliability. The AACCUP instrument for program accreditation was adopted with some modifications based on the needs of the present study. Evaluation of the AACCUP indicators for research and extension was done with some rephrasing of sentences in each category. 


\section{Research Procedure:-}

Before the questionnaires were distributed, permission to conduct the study was requested from the campus director, and likewise solicited endorsement from the head of the sample institution involved in the study. Likewise, the assistance of some faculty members of the involved institutions was solicited in order that the questionnaires be accomplished and retrieved on the target time. Unobtrusive observation, ocular inspection and documentary analysis was undertaken in order to have a clearer understanding of the results of the study.

\section{Statistical Treatment of Data:-}

Appropriate descriptive statistics was used to define the profile of research and extension programs of the College of Teacher Education at LSPU. The data were retrieved and tallied for frequencies and percentages and tabulated for clarity of presentation. Mean ratings and standard deviations were utilized to determine the perceived extent of compliance of CTE on the status of their research and extension programs. Multiple Regression Analysis technique was used to determine the significant relationship of the extent of compliance of CTE on the quality research and extension programs with respondent-related factors, and institution-related variables.

\section{Results of The Study:-}

\section{Respondent-Related Factors:-}

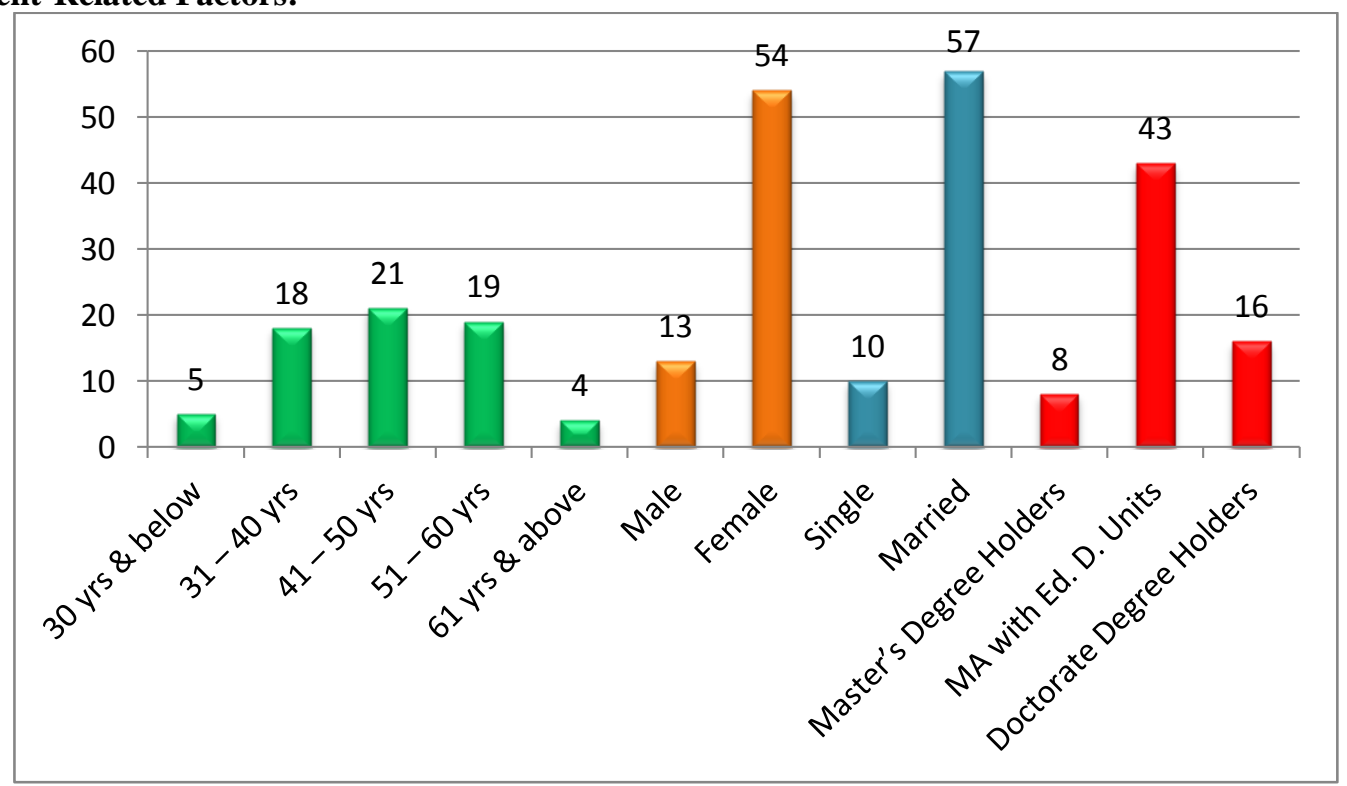

Figure 2:- Profile of the respondents

The 67 respondents of the study represented the deans, directors, faculty and staff involved in research and extension of the CTE at LSPU. Out of 67 respondents, 31 percent are between 41 and 50 years of age, 28 percent are between 51 and 60 years old and 27 percent belong to 31 and 40 years of age. Likewise, majority of them are female (81 percent); 79 percent are married; and doctorate degree holders and MA degree holders with Ed.D. units (31.57 percent, 26.31 percent).

Perception of Respondent as Researcher and/ or Extensionist:-

Table 1:- Summary of Perception of Respondent as Researcher and/ or Extensionist

\begin{tabular}{|l|c|c|c|}
\hline Indicators & Mean & SD & Interpretation \\
\hline 1. Competence & $\mathbf{5 . 7 9}$ & $\mathbf{0 . 8 5}$ & VH \\
\hline 2. Commitment & $\mathbf{5 . 8 0}$ & $\mathbf{0 . 9 1}$ & VH \\
\hline 3. Work attitudes & $\mathbf{6 . 1 5}$ & $\mathbf{0 . 7 4}$ & $\mathbf{E}$ \\
\hline OVERALL & $\mathbf{5 . 9 1}$ & $\mathbf{0 . 8 3}$ & H \\
\hline
\end{tabular}

Legend: 6.15-7.00 Excellent (E); 5.29-6.14 Very High (VH); 4.43-5.28 High (H); 3.54-4.42 Average (A); 2.71-3.56 Limited (L); 1.85-2.70 Very Limited (VL); 1.00-1.84 Negligible $(N)$

The respondents from the CTE at LSPU perceived the researchers and/or extensionists as "very highly" competent, (mean=5.79). The respondents perceived the extent of their competencies in terms of the given indicators as 
"excellent" in general, and they are strongest with regard to treating their subordinates fairly, respectfully and in timely manner. On the other hand, their competencies are weakest as regards providing subordinates with jobs that offer challenges, diversity, and variety of opportunities for need satisfaction. It seems that the respondents are very confident with their competencies in doing their jobs very satisfactory and that they treat their subordinates very well, in terms of good human relations. However, it appears that the respondents feel that they are not fully satisfied with the nature of their jobs and would likely seek more opportunities to demonstrate or express their competencies and skills.

The extent of their commitment is generally "very high", (mean=5.80). Their commitment is strongest (mean=6.05) in having a drive, intensity and persistence to work hard and in helping create an atmosphere that encourages supports and sustains improvements in the organization, but weak in making certain that there is job satisfaction in pay, work itself and promotion opportunities. Perhaps, it is not enough that subordinates have assigned works to do, but more importantly, the jobs they are doing must be fitted to their competencies and abilities and that they must be properly compensated for jobs well done in order to be fully satisfied and committed.

The level of work attitudes of the respondents from the CTE is generally "excellent" (mean=6.15). Their work attitudes are best demonstrated in giving respect and dignity to work, collaborating, cooperating and engaging in healthy interaction with others, but least demonstrated in accomplishing more in less time. It may be inferred from the findings that the respondents recognize and are aware of importance of developing healthy interactions which motivated to accomplish their work and own goals. However, the respondents also feel that they do not have to be pushed towards their accomplishment and would like to do it at their own pace whenever possible. This only shows that the respondents are aware of their role in achieving both their personal goals together with that of what the college seeks to achieve.

\section{Status of CTE's Research and Extension Programs:-}

The status of Research and Extension programs of the CTE were identified and classified into three, in terms of programs and projects, accreditation level/status, funding sources.

Research programs and projects of the CTE from the time of survey noted 12 programs and projects in which is based on their research thrust and priorities as follows: Food Security; Health and Nutrition; Alternative Medicine; Ecosystem and Natural Resources Management; Institutional Capability Building; Information and Communication Technology; Industrial Technology; Gender and Development; Infrastructure Planning and Design; Infrastructure Planning and Design; Biotechnology; Poverty Alleviation; and Agriculture and Commodity Thrust. On the otherhand, extension services totaled 14 clusters, such as: Training Program and Food Production; Entrepreneurial Education; Environmental/ Ecology Concerns; Research-Based Technology Dissemination and Delivery; Community Literacy Program; Out-of-school Youth/Unemployed Adults Development Program; Publication of Information Materials; Technology Transfer, Utilization and Commercialization; BIDANI Program; Productivity Enhancement; and Food Processing.

The accreditation level of the CTE at LSPU had reached Level III in the two programs - BSED and BSIE and BEED has passed Level II accreditation status. The CTE have identified the funding sources. All the respondents from the CTE at LSPU agreed that they get their support for their research and extension programs, projects or activities from varied sources like national funding agencies such as the Department of Science and Technology (DOST), Department of Energy and Natural Resources (DENR), Department of Agriculture (DA), and the like which became their partners in their research and extension undertakings.

\section{Extent of Compliance in the Implementation of Quality Research and Extension Programs:- Compliance of CTE in the Implementation of Quality Research Programs:-}

The compliance of CTE along the following component: priorities and relevance; funding and other Resources; Implementation, monitoring, evaluation and utilization of research results/outputs; and publication and dissemination are summarized below: 
Table 2:- Summary of CTE Extent of Compliance on the Implementation of Quality Research Program

\begin{tabular}{|c|c|c|c|}
\hline Indicators & Mean & SD & Interpretation \\
\hline 1. Priorities and Relevance & 5.36 & 1.21 & VH \\
\hline 2. Funding and Other Resources & 4.22 & 1.38 & $\mathbf{A}$ \\
\hline $\begin{array}{l}\text { 3. Implementation, } \text { Monitoring, } \\
\text { Evaluation and Utilization of } \\
\text { Research Results/Outputs }\end{array}$ & 4.72 & 1.26 & $\mathbf{H}$ \\
\hline 4. Publication and Dissemination & 4.75 & 1.41 & $\mathbf{H}$ \\
\hline OVERALL & 4.76 & 1.36 & $\mathbf{H}$ \\
\hline
\end{tabular}

Legend: 6.15-7.00 Excellent (E); 5.29-6.14 Very High (VH); 4.43-5.28 High (H); 3.54-4.42 Average (A); 2.71-3.56 Limited (L); 1.85-2.70 Very Limited (VL); 1.00-1.84 Negligible $(N)$

The CTE respondents showed "very high" extent of compliance on the quality research program along priorities of relevance components (mean=5.36). With reference to the three indicators, the respondents likewise perceived very high (mean=5.57; mean=5.30) extent of compliance, in terms of having the institutions research agenda in consonance with institutional, regional and national priorities of government agencies and in having the research activities of the institution in consonance with the research agenda of the institution, respectively. But in terms of having the stakeholders participate in the formulation of the research agenda, the extent of compliance is only high (mean=5.20). These findings clearly indicate that at the current trends of survival rates when economic sufficiency is low, the CTE find it difficult to find financial resources in aid of fully implementing quality research programs through the support and assistance of individuals or group within and outside their institutions. They could not totally comply with the implementation of their research programs since their budget allocations have to be prioritized to other areas of concern besides research for the benefit/ advantages of students and faculty.

In the implementation of quality research program along funding and resources components the respondents from the CTE generally perceived the extent of compliance as average (mean=4.22). The respondents further perceived high extent of compliance (mean=4.70) in terms of the given indicators in which the institution establishes linkages with local, national international level for funding support and assistance. However, the extent of compliance is lowest (mean=3.70) in that the institution generates income from patents, licenses, and research outputs. These findings clearly indicate that at the current trends of survival rates when economic sufficiency is low, the COE find it difficult to find financial resources in aid of fully implementing quality research programs through the support and assistance of individuals or group within and outside their institutions. They could not totally comply with the implementation of their research programs since their budget allocations have to be prioritized to other areas of concern besides research for the benefit/ advantages of students and faculty.

In terms of implementation, monitoring, evaluation and utilization of research results/ outputs with regards to the implementation of quality research program, the respondents generally perceived as high (mean=4.72). Specifically, the extent of compliance is "very high" (mean=6.00) that the University has a research and development unit managed by competent and capable faculty researchers and "high" that the institution provides incentives for faculty researchers such as honoraria, grants of service credits, de-loading and others (mean=4.20). As inferred by these findings the faculty and other staff members who are in-charge of evaluation monitoring and utilization of research outputs need to be properly compensated for their jobs since their involvement and participation in the implementation of the research programs and activities will require time, efforts and financial considerations.

With regards to publication and dissemination in the implementation of quality research programs, the extent of compliance as perceived by the respondents reveal that they comply highly (mean=4.75). On the basis of the four, indicators, the extent of compliance of the respondents perceived generally high (mean=4.99). Furthermore, the extent of high compliance is highest (mean=4.90) in that the research manuscript/ reports are well-edited and written with proper style and form but at the lowest extent (mean=4.50) that the institution provides avenues for the dissemination of research results. These findings are implication that results/outputs of researches conducted mostly by faculty or students are not often recognized outside their institutions for lack of adequate dissemination of information. Most of the time, results/outputs are known only among those involved in the research programs and unknown to the rest in the academic community. 
Compliance of CTE in the Implementation of Quality Extension Program:-

Table 3:- Summary of CTE Extent of Compliance on the Implementation of Quality Extension Program

\begin{tabular}{|l|c|c|c|}
\hline Indicators & Mean & SD & Interpretation \\
\hline 1. Priorities and Relevance & $\mathbf{5 . 0 0}$ & $\mathbf{1 . 1 5}$ & $\mathbf{H}$ \\
\hline 2. Planning Components & $\mathbf{5 . 0 0}$ & $\mathbf{1 . 3 3}$ & $\mathbf{H}$ \\
\hline 3. Implementation Components & $\mathbf{5 . 0 6}$ & $\mathbf{1 . 1 9}$ & $\mathbf{H}$ \\
\hline 4. Monitoring and Evaluation Components & $\mathbf{5 . 0 4}$ & $\mathbf{1 . 2 4}$ & $\mathbf{H}$ \\
\hline 5. Funding and Resources Components & $\mathbf{4 . 4 3}$ & $\mathbf{1 . 6 4}$ & $\mathbf{H}$ \\
\hline $\begin{array}{l}\text { 6. Community Involvement \& Participation In the } \\
\text { Institution's Activities }\end{array}$ & $\mathbf{4 . 8 6}$ & $\mathbf{1 . 4 2}$ & $\mathbf{H}$ \\
\hline OVERALL & $\mathbf{4 . 7 6}$ & $\mathbf{1 . 3 6}$ & $\mathbf{H}$ \\
\hline \hline
\end{tabular}

Legend: 6.15-7.00 Excellent (E); 5.29-6.14 Very High (VH); 4.43-5.28 High (H); 3.54-4.42 Average (A); 2.71-3.56 Limited (L); 1.85-2.70 Very Limited (VL); 1.00-1.84 Negligible $(N)$

The perception of the respondents from CTE revealed an overall mean rating of 5.00 corresponding to "high" compliance, in general, along priorities and relevance in the implementation of quality extension programs. On the basis of the five (5) indicators for the priorities and relevance the extents of compliance of CTE is "very high" (mean=5.30 and 5.10, respectively), particularly that the institutions' vision/mission and goals/objectives are reflected in the extension program and activities and it complements to the curricular offerings of the institution. However, the "high" compliance is lowest $(\mathrm{x}=4.60)$ that the institution has a benchmark of the problems, needs, and resources of the community. It is implied by these findings that even if the community is the target clientele of the extension programs of the college as reflected in their vision/mission and goals/objectives, there may be possibilities that they are not capable of actually and totally meeting the needs and problems of their clientele but have to depend on their own resources only.

In the implementation of Quality Extension Program along Planning Components the respondents from the CTE generally perceived "high" compliance (mean=5.00). In terms of the three (3) indicators for planning components, the respondents perceived that the CTE comply "highly" with highest extent of compliance (mean=5.20) in that the extension program and activities that served varied clientele or groups and involvement of concerned stakeholders (administration, faculty, and students). However, the "least high" extent of compliance (mean=4.60) corresponds to having the administration, faculty, student and other stakeholders involved in identification and planning of extension program and activities. These finding are inferences that in most actual situations whatever extension program and activities that have been identified and planned by the college may not be fully implemented due to constraints and inconsistencies between and among the implementers, stakeholders and clientele.

The overall mean rating of 5.06 reflected to "high" extent of compliance of the CTE in the implementation of quality extension program along implementation components. The respondents of the college expressed their perceptions as "very highly" comply on the indicators that the extension activities are documented and there is distinct office or unit that oversee the implementation of the extension program, (mean=5.60, 5.50), respectively. However, in terms of having the extension programs transfer appropriate technology to clientele, the extent of compliance is "lowest" with a mean perception of 4.70. These findings may suggest that in the actual implementation of extension programs and activities, there is usually the problem of financial resources that inhibits the implementers from reaching out to their target clientele and have them benefited by their extension programs.

In terms of monitoring and evaluation in the implementation of quality extension program the respondents from the CTE perceive "very high" compliance (mean=5.04). With reference to the given indicators for monitoring and evaluation, the extent of compliance is generally "high" compliance (mean=5.20, 5.10, 4.70) particularly in five out of the six indicators. However, the CTE perceived with "very high" compliance (mean=5.40) in having monitoring/evaluation instruments or processes available on file. Likewise, the lowest (mean=4.70) for the least 
high compliance is for the on time submission of accomplishment and terminal reports. These findings seem to imply that records and files about monitoring and evaluation in the implementation of quality extension services are accessible and transparent to the stakeholders but may bring forth doubts/mistrusts or lack of confidence among them.

According to the perceptions of the respondents from the CTE, the overall mean rating (4.43) corresponds to "high" extent of compliance in the implementation of quality extension program. The CTE respondents exhibit "high" compliance to the four (4) indicators but the compliance is highest (mean $=4.50$, respectively) that there is definite and approved budgetary allocation for the extension programs, and the institutions sources out additional funding from other agencies, and lowest (mean=4.30) in sourcing out technical assistance and services inputs from other agencies. The findings clearly indicate that the CTE comply with what is expected and required of them to implement quality extension program regardless of budgetary deficiencies and difficulties.

The extent of compliance of CTE on the implementation of quality extension programs along community involvement and participation in institutions activities is perceived by the respondents generally "high" (mean= 4.86). In terms of the given indicators, the respondents further perceived that the extent of compliance which is generally "high" (mean=5.25) and are similarly "high" for other indicators. However, the extent of compliance is highest (mean=5.00) with regards to the utilization of technology/knowledge/skills learned/acquired from the extension activities and lowest $($ mean=4,70) in planning. These findings are implications that the respondents have probably observed and actually experienced inadequate planning on the part of the stakeholders that if done very carefully and very thoroughly, the target clientele of the extension programs could have learned and acquired more knowledge and skills for full utilization in practice.

\section{Relationship Between Quality Research Programs and Other Related Factors:-}

This section presents the findings and answers to the research hypothesis stating that the respondent-related factors and institution-related variables taken singly or in combination do not significantly influence the quality research programs of the CTE at LSPU. The multiple regression analysis technique was employed to determine the significance of the relationship between the related factors (independent variables) and quality research programs (dependent variables). Each indicator of quality is regressed with the seven (7) respondent-related factors and (3) institutional-related variables.

Table 4:- Regression of Quality Research Program

\begin{tabular}{|c|c|c|c|c|}
\hline \multirow[t]{2}{*}{ Related Factors } & $\mathrm{A}$ & $\mathrm{B}$ & $\mathrm{C}$ & $\mathrm{D}$ \\
\hline & Beta & Beta & Beta & Beta \\
\hline Age & - & - & - & - \\
\hline Gender & - & .097 & - & - \\
\hline Civil status & .270 & .210 & .242 & .174 \\
\hline Educational Attainment & - & -.204 & -.151 & - \\
\hline Competence & - & - & .188 & - \\
\hline Commitments & .247 & - & - & - \\
\hline Work Attitude & .170 & .197 & .363 & .461 \\
\hline Programs and Projects & -.100 & -.120 & -.150 & -.147 \\
\hline Accreditation Status & -.180 & - & -.104 & - \\
\hline Funding Sources & - & - & - & - \\
\hline R-Square & .625 & .681 & .605 & .597 \\
\hline Adjusted R-Square & .619 & .675 & .597 & .590 \\
\hline F Value & 95.471 & 122.218 & 69.920 & 84.781 \\
\hline Significance & .000 & .000 & .000 & .000 \\
\hline
\end{tabular}

Note: $N=67 ; A=$ Priorities and Relevance; $B=$ Funding and Other Resources; $C=$ Implementation, Monitoring, Evaluation, and Utilization of Results/Outputs; D=Publication and Dissemination

The significance level of F-value is .000 showing that the equation is significant. The regression of research program in terms of priorities and relevance on respondent-related factors and institution related variables reveals that there are five variables that influence the quality of research programs among the respondents of the CTE at LSPU. Commitment $($ beta $=.247, \mathrm{p}=.007)$, work attitude (beta $=.170, \mathrm{p}=.057)$, civil status $(\mathrm{beta}=.270, \mathrm{p}=.000)$ accreditation 
status (beta=-.180, $\mathrm{p}=.000$ ); and programs and projects ( $\mathrm{beta}=-.100, \mathrm{p}<.05$ ) significantly provide an explanatory power of 61.92 on research programs. Research is a scientific approach in identifying and solving problems and as such is the most potential tool in generating knowledge, methods, and techniques for the attainment of the desired quality of life. Research can be used to improve system's effectiveness and efficiency in relation to how the educational leaders increased the research and development capabilities of institution (Camarao, as cited by Callo,2005). Accordingly, it is unrealistic to expect quality researches from the college due to the reported inadequacy of government support to research development in a university. (Navarro, 1999).

The result of regression analysis of funding and other resources factor for quality research programs on the institution-related factors. Among the eight indicators of the independent variables, when regressed to research program in terms of funding and other resources, there were four that reveal significant results. Results show that the $67.5 \%$ value of the adjusted $\mathrm{R}$ square significantly provides the explanatory power on the quality of research programs. It can be gleaned from Table 24 that there are five (5) predictors of quality research programs. Respondent-related factors in terms of work attitude (beta=.197, $\mathrm{p}=.026$ ), gender (beta=.097, $\mathrm{p}=.099$ ), civil status (beta $=.210, \mathrm{p}=.003)$, educational attainment (beta=-.204, $\mathrm{p}=.003)$, and programs and projects $(\mathrm{beta}=.120, \mathrm{p}=.002)$ are significantly related to funding and other resources factors on research programs. In some cases, state universities already establish research agenda in helping and networking faculty and other staff in their undertakings by allocating funds. Likewise, in as much as the goal of the institution is to be known for quality research output, it is expected that they provide facilities and equipment for easy access of information. The level of work attitude is "very high" since faculty and other staff they are motivated to anticipate improvement and development opportunities based on their own skills. Since CTE respondents are aware of their roles in the pursuit of the university programs and projects to promote national development, they have remarkable agenda along research and extension programs. They even possess the characteristic the best staff and personnel who can even delegate responsibilities and have alternative plans to meet changes, needs, and circumstances.

The regression analysis reveals the adjusted $\mathrm{R}$-square of $25 \%$ that reinforces the explanatory power of the related variables. Competence (beta $=.188, \mathrm{p}=.030$ ), work attitude (beta=.363, $\mathrm{p}=.000)$, civil status $($ beta $=.242, \mathrm{p}=.001$ ), educational attainment (beta $=.151, \mathrm{p}=.026$ ), programs and projects (beta=-.150, $\mathrm{p}=.001$ ) and accreditation status (beta=-.104, $\mathrm{p}=.019$ ) of the respondents can be associated to the high implementation, monitoring, evaluation and utilization of research results/outputs. The "high" to "very high" ratings of personnel in terms of competence and work attitude will result to a high implementation of research outputs, thus promoting quality research programs among CTE. Further the influence of the predictors is expressed by the $59.7 \%$ of the adjusted R-square value in the equation.

The regression of quality research programs in terms of publication and dissemination factor on the respondentrelated and institution-related factors reveal that there are three (3) variables that influence quality research programs. The F-value of 84.781 is significant at .000 levels. The regression analysis reveals that there are three predictors in the respondent-related factors that positively influence the quality research programs of the CTE. Work Attitude (beta $=.461, \mathrm{p}=.000$ ), civil status $(\mathrm{beta}=.174, \mathrm{p}=.010$ ), and programs and projects $(\mathrm{beta}=-.147, \mathrm{p}=.001)$ are associated with "high" compliance in the publication and dissemination of research programs. The CTE provides awareness for the dissemination of research outputs or acquisition of techniques and skills in the form of fora, conference, seminars, in-house trainings and other media. Likewise, CTE motivate their faculty and personnel to have regular publication of research journals and maintains library exchange of research publication. Programs and projects are considered good predictors to have quality research programs are revealed by the $59 \%$ explanatory power of the adjusted $\mathrm{R}$-square value.

\section{Relationship between Quality Extension Programs and Other Related Factors:-}

This section presents the findings and answers to the research hypothesis stating that the respondent-related factors and institution-related variables taken singly or in combination do not significantly influence the quality extension programs of the CTE at LSPU. The multiple regression analysis technique was employed to determine the significance of the relationship between the related factors (independent variables) and quality extension programs (dependent variables). Each indicator of quality is regressed with the seven (7) respondent-related factors and (3) institutional-related variables. 
Table 4:- Regression of Quality Extension Program

\begin{tabular}{|c|c|c|c|c|c|}
\hline \multirow[t]{2}{*}{ Related Factors } & $\mathrm{A}$ & $\mathrm{B}$ & $\mathrm{C}$ & $\mathrm{D}$ & $\mathrm{E}$ \\
\hline & Beta & Beta & Beta & Beta & Beta \\
\hline Age & - & -.137 & - & - & - \\
\hline Gender & - & - & - & - & - \\
\hline Civil status & .159 & - & - & .174 & .194 \\
\hline Educational Attainment & - & - & - & - & - \\
\hline Competence & .174 & - & .205 & - & - \\
\hline Commitments & - & - & - & - & .201 \\
\hline Work Attitude & .273 & .316 & .305 & .461 & .259 \\
\hline Programs and Projects & - & .515 & - & -.147 & -.106 \\
\hline Accreditation Status & -.114 & - & -.135 & - & -.193 \\
\hline Funding Sources & - & - & - & - & - \\
\hline R-Square & .489 & .441 & .535 & .597 & .616 \\
\hline Adjusted R-Square & .482 & .436 & .529 & .590 & .609 \\
\hline F Value & 73.259 & 91.152 & 88.121 & 84.781 & 91.743 \\
\hline Significance & .000 & .000 & .000 & .000 & .000 \\
\hline
\end{tabular}

Note: N=67; $A=$ Priorities and Relevance; $B=$ Planning Factor; C=Implementation, Monitoring and Evaluation; $D=$ Funding and Other Resources; $E=$ Community Involvement and Participation in the Institution's Activities

The regression of quality extension programs on Priorities and Relevance components and respondent-related and institution-related factors reveal that there are four 43) variables that are found to have significant influence with the F-value of 73.259 at 0.000 level of significance. Civil status (beta=.159,p=.0-25), work values (beta=.273, $\mathrm{p}=.002$ ), competence (beta $=.174, \mathrm{p}=.083$ ) and accreditation status (beta $=-.114, \mathrm{p}=.019$ ). This means that the higher the degree of competence and work values of the respondents, the higher the level of compliance of the College under study in terms of the stated measures of quality extension programs. The significant effect of the civil status vis-àvis priorities and relevance of extension programs might be linked to the high level of competence and work attitude demonstrated by the married respondents as compared to their counterpart. This can be attributed to the fact that they are more mature, responsible in considering the work array of experiences which made them decide and act accordingly.

However, the negative results on accreditation status may imply that the level of accreditation has profound influence on setting the priorities and defining relevance of the extension programs as part of its quality management. Since accreditation status would require certain level for extension programs, it could then be expected that as the accreditation level increases, there is a corresponding decrease on the level of compliance along with priorities and relevance.

The table shows regression of planning component of extension programs on respondent-related and institutionrelated variables. Three (3) indicators Age (beta= -.173, $\mathrm{p}=.058$ ), work attitude (beta=.316, $\mathrm{p}=.000$ ) and programs and projects (beta=.515, $\mathrm{p}=.000$ ). The implication of negative significant influence of age to the quality extension program with respect to planning functions of the respondents denotes that the younger the respondents are the more they are capable of handling the stated extension function, probably because their state of health both physical and mental can easily adapt to the needed vigor of an extensionist for a successful endeavor.

The table shows regression of monitoring and evaluation components on the quality extension program controlling for respondent-related factors. As indicated in the data, among the seven (7) control variables, three (3) came out as predictors of monitoring and evaluation of extension program. The positive beta coefficient for civil status (beta=.171, $\mathrm{p}=.014$ ), work attitude (beta=.000, $\mathrm{p}=.347$ ) and commitment (beta=.218, $\mathrm{p}=.016$ ) implies that married respondents tend to show positive outlook toward monitoring and evaluating extension programs, projects and activities which require long hours of work and critical analysis.

Those predictors may be attributed to their experiences associated with family matters, hence, they become significant effectors in attaining successful and well-organized extension program.

The positive effect of the said factors is indicative of a greater effort in maintaining positive work attitude and high level of commitment among the people involved in the program, specifically the deans, directors, faculty, staff, and 
students from the College of Education, thus ensuring effective and efficient monitoring, and evaluation of extension services for the clientele.

The result of regression of funding and other resources as component of quality extension programs is presented in the table. It can be seen that three (3) factors significantly predict the quality of extension programs along funding and other resources components. The positive beta coefficients, for the control variables; namely: work attitude, (beta $=.305, \mathrm{p}=.000$ ), competence, (beta $=.205, \mathrm{p}=.045$ ), denotes that the quality of extension program as measured in terms of funding and other resources is a product of composite characteristics of the person involved to attain quality extension program, such as willingness and self-immersion. However, accreditation status (beta= $-.135, \mathrm{p}=.004$ ) implies that significant difference on the funding and other resources component was evident. As the higher level of accreditation of the intuition tend to comply with minimum standards for each level. The positive beta coefficients, for the control variables; namely: work attitude, (beta=.305, $\mathrm{p}=.001$ ), competence, (beta=.205, $\mathrm{p}=.045$ ), denotes that the quality of extension program as measured in terms of funding and other resources is a product of composite characteristics of the person involved to attain quality extension program, such as willingness and self-immersion.

The regression of the community involvement factor shows that the $60.9 \%$ value of adjusted R-square significantly provides the explanatory power on quality of extension programs. The positive beta coefficient for the control variables; civil status, (beta=.194, $\mathrm{p}=.000$ ), means that married individuals tend to be more sociable and can easily adjust to cultural diversity that might be encountered in the community where extension activities are undertaken, simply because they are more exposed to the needs of the family or clientele. Similarly, work attitude, (beta $=.259, \mathrm{p}=.000$ ), and commitment, (beta=.201, $\mathrm{p}=.000$ ), means that the quality of extension program as measured in terms of the extent of community involvement and participation in institutions activities is a characteristic inherent to an individual accreditation status (beta $=-.193, \mathrm{p}=.000$ ), and programs and projects (beta $=-.106$, $\mathrm{p}=.000$ ) contribute to the attainment of quality extension program.

Successful implementation of extension programs and projects cannot be done not only by a single person. It is a byproduct of collaborative effort and cooperation of all involved; hence, the purpose of the extension program is to make the presence of the institution felt in the community. This can be made possible by those individuals who commit themselves and develop proper work attitude in any extension undertaking.

The noted significant difference on the extent of compliance indicates that the CTE compliance on quality extension program as to community involvement and participation component can be attributed to the fact values among the persons involved vary, thus varied outcomes are expected tantamount to their competence, commitment and work attitude.

On the other hand, accreditation level requires the college on community involvement and participation and more visible outreach programs which are reflected in the program that is carefully planned, implemented, monitored and evaluated. A broader in scope and ensure sustainability in it. It can be said that accreditation level is therefore a mechanism that influences higher compliance on community involvement and participation component of the quality extension programs.

\section{Conclusion:-}

The quality of research and extension programs is significantly influenced by the respondent-related factors and institution-related variables, when taken singly, or in combination. Thus the null hypothesis is partially sustained.

\section{Recommendations:-}

In view of the conclusions of this study, the following recommendations are hereby presented:

1. In-house reviews may be conducted on a periodic basis. Results of researches conducted may be disseminated to local and national instrumentalities who are interested to conduct collaborative research and thereby become potential financiers of future research projects.

2. Noted achievements of the College in terms of the components of the extension programs call for the institutionalization of a functional and highly visible community service program. This in reality may be used as a public relation program of every institution and thus make their presence felt in the community.

3. Since the data on the extent of the level of compliance of the College on the components of the research program exhibited significant difference in reference to the level of accreditation, it is therefore recommended 
that development of a functional research program be conducted along with the pursuance of higher level of accreditation. With an aspiration to achieve higher level of accreditation come strong desires to develop a research culture in the organization.

4. Publication and dissemination of research outputs maybe intensified through regular publication in research journal and library exchange research publication and may be brought into the attention of the general public for practical application.

\section{Bibliography:-}

1. Abanto, Librada L. (2005). An Introduction to Extension Services: Programs and Community Involvement. LSPC, Sta. Cruz Campus, Extension Department.

2. Annuevo, C.M. (1997) Learning Gender Justice: The Challenge for Adult Education in the $21^{\text {st }}$ Century. Manila: FNB Publishers, Inc,.

3. Bloom, Benjamin S. (1977) Handbook on Formative and Summative Evaluation of Student Learning. New York: McGraw Hill Co.

4. Bowling, Chester J and Brahm, Barbara A. (2001) Evaluating Evaluation - What We've Learned. University of Illinois.

5. Calmorin, Laurintina P and Calmorin, Melchor A. (2000). Methods of Research and Thesis Writing. Quezon City: Rex Printing Company, Inc.

6. Camarao, Fedeserio C. (1994) Technology Education in the Philippines, Manila: National Bookstore.

7. Colinares, N.S. (2002) Teacher Education Issues and the Teacher. Nothern Samar: Tres Niñas Printing Press.

8. Davis, Keith. 1997) Human Behavior at Work. Fifth Edition New York: McGrew-Hill Book Company.

9. Deim, Keith. (2001) Using Research Methods to Evaluate Your Extension Program. Educational Design Rutgers, The State University of New Jersey.

10. De Chavez, Ernesto M. (1998) On Research and Extension Services. Vol. VI, No. 1, Graduate Journal PBMIT.

11. French, Elizabeth. (1995).The Relationship of Achievement to Problem Solving Effectiveness. Abnormal Social Psychology. New York: Houghton Miffin Co.

12. Gibson, James L. et.al. (2006) Organizations Behavior, Structure, Processes. Twelfth Edition, New York: McGraw Hill/Irwin.

13. Hobart, Wendy. (1997) Critical Factors for Successful Programs. Battle Creek Michigan, W.K. Kellogg Foundation.

14. Jones, E.J.(1986) Investing in Rural Extension. Elsevier Applied Science Publishers, London New York.

15. Jain, R.K., et.al. (1997) Management of Research and Development, New York, John Wiley and Sons, Inc.

16. Kelly, William. .(1956) Educational Psychology. Milwaukee: The Bruce Publishing Co.

17. Manuel, Bienvinido B. (1989) New Thrust in Philippine Education. Volume II, Quipo, Manila: Current Events Digest, Inc.

18. Manske, Fred A. Jr. (1987) Secrets of Effective Leadership. USA: Leadership and Education Development.

19. Medley, Donald M. et.al. (1994 )Management - Based Evaluation of Teacher Performance. New York: Longman Press

20. .Nolledo, Jose N. (1995) The Education Act of the Philippines Annotated. Revised Edition. National Bookstore, Manila.

21. Rogers, Carl B. (1942) Client-Central Therapy: Its Practice Theory. New York: Houghton Mifflin Co.

22. Roling, N. (1988) Extension Science Information Systems in Agricultural Development. Cambridge, Great Britain: Cambridge University.

23. Ruiz, Macario B. 1988) Evaluation and Measurement of Philippine School Elementary Principles and Techniques. Quezon City: PR Garcia Publishing Co.

24. Tuckman, Bruce W. (1975). Measuring Educational Outcomes. New York: Harcourt Bruce Jovanovich.

25. Van Den Ban, A.W. and H.S. Hawkins. Agricultural Extension. New York: Longman Scientific and Technical Co., Published in US with John Wiley and Sons Inc.

26. Villegas, Emelina S. "Education for Development” IBON Partnership in Education for Development, Sta. Mesa, Manila, June, 1999.

\section{Documents:-}

1987 Philippine Constitution

The Philippine Agenda of 1997.

NBC 461, Qualitative Contribution Evaluation (QCE) Manual of Operation

Quality Audit Handbook, 2000 
AACCUP Accreditation Handbook, 1998.

Accrediting Agency for Chartered Colleges and Universities of the Philippines Accreditation Instrument for Area VResearch.

Accrediting Agency for Chartered Colleges and Universities of the Philippines Accreditation Instrument for Area VI-Extension and Community Involvement.

Accrediting Agency for Chartered Colleges and Universities of the Philippines Accreditation Instrument for Area IVision, Mission, Goals and Objectives

"Managing Municipal Agricultural Extension in the Philippines Manual". Produced by: Agricultural Training Institute.

LSPU, Annual Report 2008

Organizational Performance Indicator Framework, FY 2009 A Book of Outputs of State Universities and Colleges, Department of Budget and Management, Malacañang, Manila, May 2009.

\section{Journals:-}

Arnn, John W. and Mangiers, John N. "Effective Leadership for Effective Schools: A Survey of Principal Attitudes, "National Association of the Secondary School Principals, February 1988.

Delors, Jacques. "Learning: the Treasure Within", Reports of the International Commission of Education for $21^{\text {st }}$ Century, Trance, UNESCO Publishing, 2000.

FAO Study on the Philippine Agricultural Extension in the Philippines, Department of Agriculture 1989.

Rosenholtz, Susan J. "Effective Schools: Interpreting the Evidence." American Journal of Education. Vol. 93, No 3, May 1985.

Sison, Obdulia F. "Internatinal Course for Rural Extension Trainers" Module 1.1 An Overview of Agricultural Extension, UPLB, Los Baños, 1994.

Sison, Lilian J. "Management of Instructional Research: Focus on Academic. The PSERE Journal. Vol. 1 May 1996.

Holta, S. and Malki, P. "Response of Finish Higher Education to the National Information Society," Higher Educational Policy, 13 (1), 231-234, 2000.

Report on Global Consultation on Agricultural Extension FAO 1989 Rome Italy (4-8 December 1989) Food and Agricultural Organization of the United Nations.

"Education Convergence and Partnership" UPLB Ugnayan ng Pahinungod Accomplishment Report 1999-2004.

\section{Unpublished Materials:-}

Aglubat, Juan. 1992. "Effect of Faculty Development Program on Performance, Morale of the Faculty in State Tertiary Institutions in Region III," Dissertation, TUP, Manila,

Aramsi, Wachiparan. 1999. "Performance Effectiveness of Faculty Members of the Technical Education and Technical Campuses Offering BS Degree in Thailand". Dissertation, TUP, Manila,

Buemio, Henry B. 2006. "Community Extension Program of Saint Paul College of Ilocus Sur", Master's Thesis, University of Northern Philippines, Vigan City,

Callo, Eden C. 2005. "Organizational Climate and Performance of Selected State Universities and Colleges". Dissertation, TUP, Manila,

Contaoi, Mario R. 2003 . "The Effectiveness of the Extension Program of the University of Northern Philippines, University of Northern Philippines,

David, Ma. Assumpta M. 1990. "Factors Affecting the Organizational and Occupational Commitment of Lay Teachers of the RVM Schools in the Philippines." Dissertation, UP Diliman, Quezon City,

De La Virgen, Senando A. 1999. "Organizational Climate, Its Influence on Performance and Promotion". Dissertation. TUP, Manila,

De Alban, Ma. Teresa G. 1998. "Status, Performance and Prospects of the Community Extension Programs of the Universities in the Bicol Region" Doctoral Dissertation, University of Northern Philippines, Iriga City.

De La Cruz, Imelda C. 2004. "An Assessment of the Extension Support System in the Micro Home Food Processing Industry in Laguna, Philippines". Doctoral Dissertation, University of the Philippines, Los Baños.

Duncan, Stephen F. et.al. 2000. .EDUFAIIM: A Successful Program Helping Empower Rural Families Toward SelfReliance. A Community Research Paper Presented to Brigham Young University, Provo, Utah.

Guevarra, Perla M. 2005. "Performance of Cooperating Teachers in Selected Technological Institutions: Directions for Student Teaching Program Effectiveness". Dissertation, TUP, Manila. 
Hostede, Ronald and Gruidl, John. 2000. "Evaluation of Capacity-Building Programs: A Learning Organization Approach." A Paper presented to Department of Sociology and Cooperative Extension Service University of Kentucky Lexington, Kentucky.

Limpiada, Rogel L. 2008. "Evaluation of the Quality of Research and Extension Programs in Selected HEIs in the CALABARZON Region". Dissertation, Polytechnic University of the Philippines, Manila.

Manalo, Elizabeth T. 1992. "Principal's Instructional Leadership Behaviors, Teachers' Job Satisfaction and Performance and Pupils' Academic Achievements". Dissertation. University of the Philippines, Diliman.

Navarro, Leonardo L. 1999. "Educational Networking of State Colleges and Universities in Region III and Institutional Performance." Dissertation. Technological University of the Philippines.

Pasicolan, Dante P. 2001. "The Extension Program of Tertiary Schools in Cagayan" Doctoral Dissertation, Cagayan State University, Tuguegarao City.

Parcon, Arturo P. 1991 . "Factors Influencing The Organizational Effectiveness of Technical Education Institutes". Dissertation. University of the Philippines, Manila.

Salvador, Nelia T. 2005. "Organizational Factor and Performance in Research, Extension Services and Production of Selected SUs in CALABARZON. Dissertation, TUP, Manila.

Sison, Flordeliza M. 1999. "The Extension Programs of State Universities and Colleges in Region VIII: Their Impact on Community Development", Doctoral Dissertation, Philippine Normal University, Manila.

Trinidad, R.G. 1999 . "Rural Women's Participation in Farm and Non-Farm Activities in Camalaniugan, Cagayan", Doctoral Dissertation, University of the Philippines, Los Baños.

Versano, Dolores D. 2008. "Predictors of Faculty Creativity and Performance in Research, Extension Services, and Production in Laguna State Polytechnic University System.” Dissertation, TUP, Manila. 